\title{
Crystallization of calcium carbonate in a large-scale push-pull heat storage test in the Upper Jurassic carbonate aquifer
}

\author{
Martina Ueckert ${ }^{1^{*}}$ (1), Carina Wismeth ${ }^{1}$ and Thomas Baumann ${ }^{2}$
}

\author{
*Correspondence: \\ martina.ueckert@tum.de \\ ${ }^{1}$ Institute of Hydrochemistry, \\ Technical University \\ of Munich, Marchioninistr. 17 \\ 81377 Munich, Germany \\ Full list of author information \\ is available at the end of the \\ article
}

\begin{abstract}
Crystallization of carbonates is a key process affecting the operation of geothermal facilities and aquifer heat storage systems. The crystals formed in an aquifer heat storage test in the Upper Jurassic carbonate aquifer were investigated at injection temperatures of $65^{\circ} \mathrm{C}$ to $110^{\circ} \mathrm{C}$, with varying $\mathrm{CO}_{2}$ partial pressures, and varying $\mathrm{Mg} / \mathrm{Ca}$ ratios. Water samples were directly filtrated, and analyzed by SEM/EDX. Complementary autoclave experiments were run. In the autoclave experiments with tap water, aragonite crystals dominated at all temperatures $\left(45-110^{\circ} \mathrm{C}\right)$. In the autoclave experiments with ultra-pure water, calcite crystals dominated at the same temperatures. In the field test, mainly calcite crystals were found up to temperatures of $90^{\circ} \mathrm{C}$. Only at very high temperatures of $110^{\circ} \mathrm{C}$ aragonite crystallization prevailed. $\mathrm{CO}_{2}$ partial pressure varied especially between injection and production stages. Mg/Ca ratio varied through all stages, and depended on the dissolution of the rock matrix. Together with the autoclave experiments, this study suggest that temperature and $\mathrm{Mg} / \mathrm{Ca}$ ratio had no influence on the crystallization, and only supersaturation affected the $\mathrm{CaO}_{3}$ polymorphs. We further assume that we produced initially injected crystals back during the following production stage. That results in the assumption that existing particles can maintain an equilibrium in the dispersion, and reduce precipitation on surfaces like pipes and heat exchangers.
\end{abstract}

Keywords: $\mathrm{CaCO}_{3}$ polymorphs, Calcite, Aragonite, Carbonate aquifer, Autoclave experiments

\section{Introduction}

The efficiency of geothermal power generation sites as well as aquifer thermal energy storage in carbonate aquifers is still affected by precipitations of calcium carbonate polymorphs (Lee 2013; Mundhenk et al. 2013; Ueckert and Baumann 2019). Precipitation of calcium carbonate in geothermal systems is mainly caused by temperature and pressure changes (Baumann et al. 2017).

Precipitates of a geothermal or thermal energy storage system are usually investigated by analyzing the occurring scalings (see e.g., Wanner et al. 2017). On the other hand, there are only very few studies addressing crystallization processes or the particle load of geothermal water (Ueckert 2016; Wolfgramm et al. 2011). As a consequence, little is 
known about the crystallization process of the polymorphic forms of calcium carbonate in geothermal systems. The crystallization itself has been studied under well-defined laboratory conditions for several years (see e.g., Reddy and Nancollas 1970) and is still a major research topic (see e.g., Schmidt et al. 2019).

In classical nucleation theory, crystallization is divided into nucleation and crystal growth. While nucleation is depends on the supersaturation of the solution, crystal growth is determined by the diffusion of atoms or ions to and on the surface of the nuclei and their following incorporation into the lattice. On the other hand, nonclassical crystallization theory was introduced to explain, e.g., the crystallization via amorphous precursors or the formation of mesocrystals (De Yoreo and Vekilov 2003; Meldrum and Cölfen 2008). It is important to explain the crystallization of calcium carbonate polymorphs, because the (meta)stable forms of calcium carbonate vaterite, calcite and aragonite crystallize often via amorphous calcium carbonate (ACC) precursor. The transformation of ACC to the crystalline polymorphs is extremely fast $[<2 \mathrm{~min}$ at $25^{\circ} \mathrm{C}$ (Rodriguez-Blanco et al. 2011)], and ACC is usually not stable in natural systems.

The concept of homogeneous and heterogeneous nucleation was introduced in the literature, and plays an important role in calcium carbonate crystallization. Once a solution reaches a critical supersaturation, a nucleus can spontaneously form, which is called homogeneous nucleation. In heterogeneous nucleation, a surface is already existing, which makes nucleation energetically less demanding (Meldrum and Cölfen 2008).

To describe the crystallization of calcite, a diffusion-reaction model was suggested. Here, calcite growth is regulated by two processes: mass transport and surface reaction (see e.g., Tai et al. 2006). Wang et al. (2013) supported this for calcium carbonate polymorphs experimentally. According to their study, calcite crystallization is favored at high concentration gradients, whereas high temperatures favor aragonite crystallization. Already Wray and Daniels (1956) reported that aragonite is prevailing over calcite at $45^{\circ} \mathrm{C}$. Ahn et al. (2005) postulated that supersaturation of the solution is controlling the growth of the polymorphs and the affinity to crystallize as vaterite, calcite, and aragonite increases with decreasing supersaturation. Other cations, especially magnesium ions, inhibit crystallization processes of calcite (Chen et al. 2006; Tai and Chien 1998; Morse et al. 1997; Reddy and Nancollas 1976; Zhang and Dawe 2000), due to their incorporation into the calcite lattice. However, the presence of magnesium ions is reported to accelerate the crystallization of aragonite (Berner 1975). Furthermore, the availability of magnesium ions inhibits the transformation of vaterite into calcite (Kitamura 2001). Niedermayr et al. (2013) state that the coexisting presence of polyaspartic acid and magnesium ions favor the formation of calcite over aragonite and vaterite. Also, the influence of sulfate ions is discussed. Bots et al. (2011) performed laboratory experiments to see the influence of sulfate ions in combination with $\mathrm{Mg} / \mathrm{Ca}$ ratios on the precipitation of the $\mathrm{CaCO}_{3}$ polymorphs. Without sulfate or magnesium ions in the solution, calcite crystals prevailed. Without sulfate ions in the solution, aragonite was the dominant polymorph (> 90\%) at a $\mathrm{Mg} / \mathrm{Ca}$ ratio of 0.77 . As soon as sulfate ions (minimum of $5.1 \mathrm{mM}$ ) were added to the solution, aragonite was already at a $\mathrm{Mg} / \mathrm{Ca}$ ratio of 0.36 , dominating the polymorph. The role of other bivalent cations, such as strontium or barium, has been investigated for several years (see e.g., Wray and Daniels 1956), and is still part of the 
main research (see e.g., Littlewood et al. 2017). But, according to them, it is likely that it favors aragonite crystallization over calcite.

Han et al. (2006) precipitated calcium carbonates by injecting a $\mathrm{CO}_{2} / N_{2}$-gas mixture into a $\mathrm{CaCl}_{2}$ solution. Vaterite formation is favored at high gas flow rates and low initial $\mathrm{CaCl}_{2}$ concentrations. An increase from 33 to 66 vol\% $\mathrm{CO}_{2}$ in the injected gas results in an increase of vaterite crystals. Aragonite needles were only observed at temperatures of $60^{\circ} \mathrm{C}$. It seemed that the bubbling time and the stirring rate are not dominant for the morphology of the carbonates. This experiment seems to be very close to the degassing of thermal water in geothermal systems. However, in this experiment $\mathrm{CO}_{2}$ serves as a source for carbonates, i.e., the equilibria in the solution are controlled by the mass transfer rates of $\mathrm{CO}_{2}$ from gas phase bubbles into the liquid phase, which at the given experimental conditions result in a net dissolution of $\mathrm{CO}_{2}$. In contrast, in geothermal systems in the Upper Jurassic carbonate aquifer in the Bavarian Molasse Basin, no gas phase is present under reservoir conditions with pressures exceeding 200 bar. Inorganic carbon is dissolved and the species distribution is controlled by the carbonic-acid-equilibrium. During production of geothermal water, gas bubbles are formed if the pressure is lower than the sum of the partial pressures of the dissolved gases (bubble point, typically $2-25$ bar). In this case, $\mathrm{CO}_{2}$ is stripped from the geothermal water. Consequently, the carbonic-acid-equilibrium is shifted to higher $\mathrm{pH}$ and precipitation of carbonates occurs. In both cases, the presence of the air-water interface at the bubble has to be considered (Baumann 2016; Baumann et al. 2017).

As seen in all these well-defined laboratory experiments, the crystallization of calcium carbonate polymorphs is very complex, and as soon as one boundary condition is changed, another polymorph might preferentially be formed.

Since the knowledge of crystallization processes is indispensable for avoiding costintensive shutdowns due to scalings, research focusing on the behavior in complex natural systems is necessary. During a push-pull heat storage test with well-defined boundary conditions, which results are described in Ueckert and Baumann (2019), additionally the crystallization of calcium carbonate polymorphs was analyzed. To support our findings, we performed experiments in a high-temperature autoclave to further reduce the degrees of freedom for the evaluation.

\section{Materials and methods}

\section{Description of the autoclave experiments}

Experiments were run in an autoclave (Midiclave, Büchi, Switzerland), which has a total volume of $1 \mathrm{~L}$ (see Fig 1 ). The autoclave was filled with $0.5 \mathrm{~L}$ of water. The rock matrix (volume of 100 resp. $150 \mathrm{~cm}^{3}$ ) was put into a stainless steel basket and submersed in water in the center of the reaction vessel. After closing the autoclave, the remaining air was exchanged with argon (99,996 Vol.\% purity, Westfalen, Germany).

Three different setups were chosen: in the first setup, a rock sample and $500 \mathrm{~mL}$ ultrapure water (= UPW, QPAK 1, Merck) were put into the reaction vessel (see Fig. 3). In the second setup, carbonate tap water (='tap water MUC'), was used instead of UPW and a defined initial $\mathrm{CO}_{2}$ partial pressure (about $5-8 \mathrm{mbar}$ at $20^{\circ} \mathrm{C}$ and a total pressure of $1.2 \mathrm{bar}$ ) was established in the reaction chamber by adding a defined volume of $\mathrm{CO}_{2}$. 


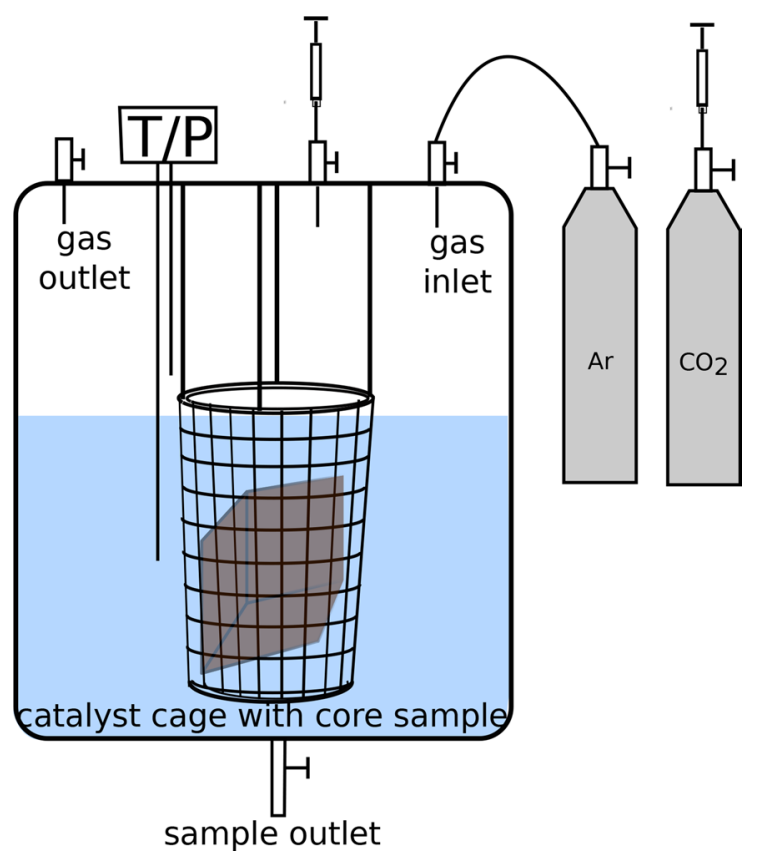

Fig. 1 Schematic overview of the autoclave experiment. The defined volume of $\mathrm{CO}_{2}$ is injected by means of a gas syringe

In the third setup, only tap water MUC was heated without a rock sample and served as a blank reference.

For each setup, five experiments were run at temperatures of $45,60,80$ and $110^{\circ} \mathrm{C}$. The autoclave was heated to the target temperature within $15 \mathrm{~min}$. At temperatures up to $80^{\circ} \mathrm{C}$, samples for fluid and particle characterization were taken at the bottom valve of the autoclave immediately after the target temperature had been reached. Samples at higher temperatures were taken after a short cooling period of $10 \mathrm{~min}$ to reach $80^{\circ} \mathrm{C}$.

The experiments with rock sample were performed once with a limestone sample (see lower picture Fig. 3), and once with a dolomite sample (see upper Fig. 3). 12 experiments were run at one rock sample, so 36 samples were taken in total.

The reaction vessel was rinsed in two steps after two experiments: first $0.8 \mathrm{~L}$ citric acid was heated, and then discarded. Afterwards 1-L ultra-pure water was filled in the autoclave and then removed.

No stirring device was used to simulate the reactions off the main flow paths. The rationale behind that is that most of the heat transfer happens in the karstified layer while reactive surface is necessary for dissolution.

\section{Description of the field experiment}

A detailed description of the heat storage test performed in the Upper Jurassic carbonate aquifer in the North East-Molasse Basin in the city Dingolfing, the operational design and the hydrogeochemical model are given in Bartels et al. (2015) and Ueckert and Baumann (2019).

The test design at the research borehole was a push-pull test with five injection stages of hot carbonate tap water (injection temperature $T_{\text {Inj }}=65,80,90,110$, and $110^{\circ} \mathrm{C}$ ) into 
a carbonate aquifer, each immediately followed by a production stage (see Fig. 2). The flow rate was set to $15 \mathrm{~L} / \mathrm{s}$ (see Table 1).

To prevent precipitates in the heat exchangers, $\mathrm{CO}_{2}$ was added prior to heating the tap water. The required concentration was calculated using the hydrogeochemical modeling software PhreeqC (Parkhurst and Appelo 2013). Taking the reaction rates of calcite precipitation and the short residence times (about $0.13 \mathrm{~s}$ ) in the heat exchanger into account, a saturation index (SI) for calcite between 0.1 and 0.2 was targeted. This slight supersaturation was intended to prevent corrosion effects in the pipes and ground-level facilities. The calculations resulted in $\mathrm{CO}_{2}$ concentrations between $90 \mathrm{mg} / \mathrm{L}$ for $T_{\text {Inj }}$ of $65^{\circ} \mathrm{C}$ and $420 \mathrm{mg} / \mathrm{L}$ for $T_{\text {Inj }}$ of $110^{\circ} \mathrm{C}$ and a resulting $\mathrm{pH}$ of 6.78 and 6.22 , respectively.

Water samples were taken at a bypass close to the well head. At temperatures exceeding $80^{\circ} \mathrm{C}$, a cooler was used to maintain safe sampling conditions. Samples were taken during injection (tap water, controlled temperature, controlled $\mathrm{CO}_{2}$ content) as well as during production (mixture of tap and aquifer water, decreasing temperature ( $\left.T_{\text {Prod }}\right)$, varying $\mathrm{CO}_{2}$ content), and were filtered immediately.

The pressure at the top of the aquifer was constant at 25.3 bar during the production stages.

\section{Matrix characterization}

The upper $20 \mathrm{~m}$ of the target aquifer at the test site are built of limestone, layered with dolomitic breccia and dolomites. The rest of the aquifer consists of dolomites and dolomitic breccia (about $200 \mathrm{~m}$ ). Dolomites were formed by dolomitization of limestones. Circulation loss occurred from 297 to $397 \mathrm{~m}$ b.s.l., and no cored drilling was possible at that depth. The evaluation of the heat storage test showed that the water is mostly flowing in a karstified structure (= main flow path), but a smaller amount of water will be transported in the surrounding pores of the rocks (Bartels et al. 2015). Crushed pieces of the core samples were used for the autoclave experiments (see Fig. 3). CT pictures of the rock samples provide data on the accessible surface area, i.e., the area at which reactions can occur under rate-limited conditions. The limestone samples show high contents of ooids and peloids (see lower picture Fig. 3, marked with a green rectangle), and no aragonite crystals were found (Bartels et al. 2015).

Calcium and magnesium ion concentrations of the rock samples were determined by microwave acid digestion, followed by ICP-MS measurements $(n=3)$. The limestone sample used in the autoclave experiment had a $\mathrm{Ca} / \mathrm{Mg}$ ratio of 22.1 , and the dolomite sample had a ratio of 1.47 (see Table 2). In total, 11 different rock samples from different depths were digested. While all limestone samples had a $\mathrm{Ca} / \mathrm{Mg}$ ratio $>15$, all dolomite samples had a ratio of 1.47-2.10 (Ueckert 2016).

\section{Hydrochemical conditions}

To assess saturation indices, as well as $p\left(\mathrm{CO}_{2}\right)$ of the field and autoclave experiments, the software PhreeqC (version 3.4.0-12927, Parkhurst and Appelo 2013), and the database phreeqc.dat was used. Thermodynamic parameters for vaterite were taken from the SITdatabase (sit.dat), those for argon and ethane were taken from the Lawrence-LivermoreNational-Laboratory database (llnl.dat), and the Peng-Robinson parameters were taken from PREOS.xls (Elliot and Lira 2013). 


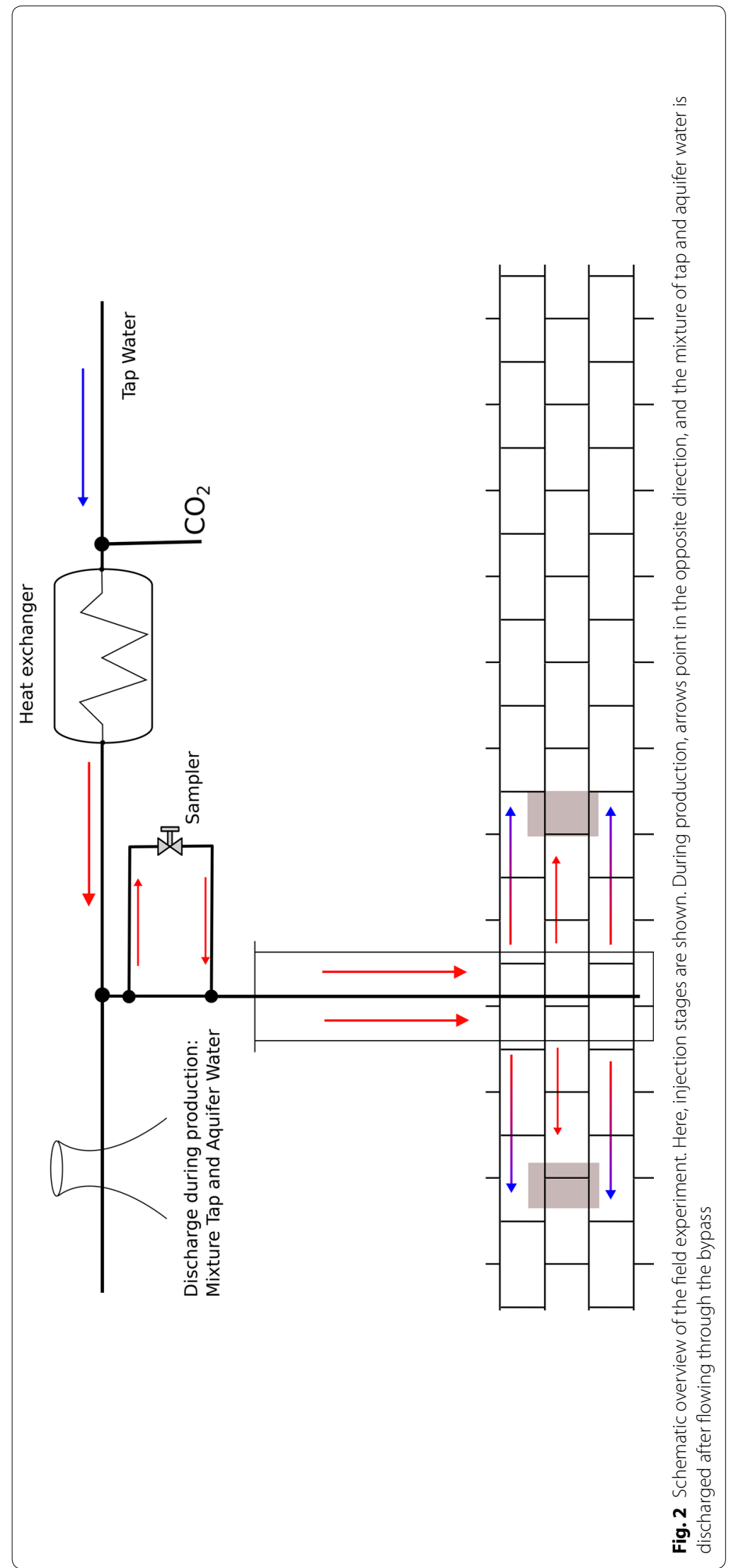


Table 1 Breakdown of the heat storage test. Ueckert and Baumann (2019)

\begin{tabular}{llllllc}
\hline Date & Time & Running time & Stage & $\dot{\boldsymbol{V}}_{\text {inj. }}$ L/s & $\dot{V}_{\text {prod. }}$ L/s & Temp. ${ }^{\circ} \mathbf{C}$ \\
\hline $2014-10-15$ & $22: 20$ & $48: 00$ & 0 & 15 & & 65 \\
$2014-10-17$ & $22: 20$ & $60: 00$ & 0 & & 15 & \\
$2014-11-24$ & $15: 15$ & $60: 00$ & 1 & 15 & & \\
$2014-11-27$ & $03: 15$ & $47: 45$ & 1 & & 15 & \\
$2014-11-29$ & $03: 00$ & $48: 00$ & 2 & 15 & & \\
$2014-12-01$ & $03: 00$ & $36: 00$ & 2 & & 15 & 110 \\
$2014-12-02$ & $15: 00$ & $48: 10$ & 3 & 15 & & \\
$2014-12-04$ & $15: 10$ & $35: 50$ & 3 & & 15 & \\
$2014-12-06$ & $03: 00$ & $48: 00$ & 4 & 15 & & \\
$2014-12-08$ & $03: 00$ & $96: 00$ & 4 & & &
\end{tabular}

The hydrochemical composition of the used tap waters (MUC and DGF) and of the reservoir water is given in Table 3.

The reservoir water contains $922 \mathrm{mg} / \mathrm{L}$ total dissolved solids and is described as $\mathrm{Na}-\mathrm{HCO}_{3}-\mathrm{Cl}$-type. The measured $\mathrm{Ca} / \mathrm{Mg}$ ratio was 1.13 , therefore a mainly dolomitic reservoir matrix (Langmuir 1971; Mayrhofer et al. 2014) along the flow paths leading to the borehole can be safely assumed. The isotopic composition of the aquifer water indicates significantly lower ambient temperatures compared to recent groundwater, thus putting the reservoir water into a glacial period. A full equilibrium with the matrix can safely be assumed for the reservoir fluids (Baumann et al. 2017). The calculated bubble point for the reservoir water was $2.9 \mathrm{bar}$, thus we can assume that no gas phase is present under reservoir conditions. The gas with the highest partial pressure is nitrogen (Ueckert and Baumann 2019).

The injected tap water DGF at the heat storage test contains $525 \mathrm{mg} / \mathrm{L}$ total dissolved solids and is characterized as $\mathrm{Ca}-\mathrm{Mg}-\mathrm{HCO}_{3}$-type. Hydrogeochemical modeling with PhreeqC results in a SI for calcite of -0.19 at $20^{\circ} \mathrm{C}$. The water is slightly undersaturated, but within the quasi-equilibrium conditions (Merkel and Planer-Friedrich 2002). Heating to $65^{\circ} \mathrm{C}$ results in a slight supersaturation $(\mathrm{SI}=0.27)$ and heating to $110^{\circ} \mathrm{C}$ results in a ninefold supersaturation $(\mathrm{SI}=0.95)$ with respect to calcite. The necessary amount of $\mathrm{CO}_{2}$ to reach a target SI of 0.1-0.2 for calcite in the heat exchanger was calculated for each temperature with PhreeqC and added prior to heating the water from a $\mathrm{CO}_{2}$ storage tank using an injection nozzle.

The tap water MUC used in the autoclave experiments was also carbonate tap water, but had a lower magnesium ion concentration and less total dissolved solids (391 mg/L). It is characterized as $\mathrm{Ca}-\mathrm{Mg}-\mathrm{HCO}_{3}$-type. Heating the water to $110^{\circ} \mathrm{C}$ results in a $\mathrm{SI}=1.47$.

\section{Filtration and particle analysis}

A custom-made filtration device manufactured in the institute's workshop (Institute of Hydrochemistry, TUM) was used (see Fig. 4). This device consists of a brass piston to drive the sample gently through a series of up to 5 filters with as little contact to air as possible. All materials in contact with the fluid are made of PTFE, PE, or PMMA, 


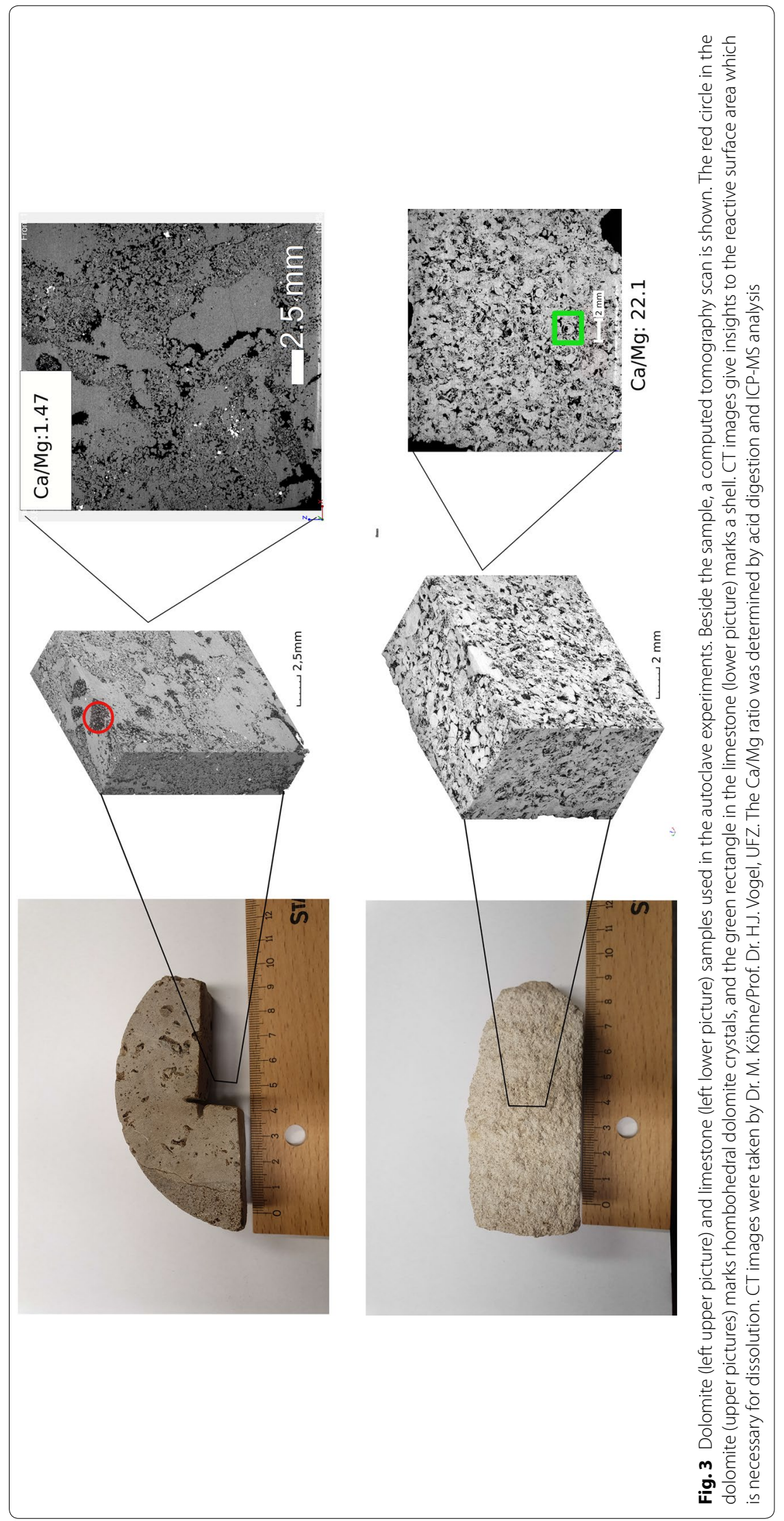


Table 2 Matrix description. Bartels et al. (2015)

\begin{tabular}{lllll}
\hline Sample & Description & Depth, $\mathbf{m}$ b.s.l. & Porosity, \% & Ca/Mg \\
\hline Limestone & $\begin{array}{l}\text { Microcrystalline grainstone } \\
\text { lincl. ooids and peloids } \\
\text { Calcite crystals }\end{array}$ & 259 & 15.7 & 22.1 \\
Dolomite & $\begin{array}{l}\text { Macrocrystalline dolomite } \\
\text { Mostly idiomorph-hypidiomorph } \\
\text { Pores up to } 2 \text { cm } \\
\text { Dolomite crystals }\end{array}$ & 397 & 4.62 & 1.47 \\
& & & & \\
\hline
\end{tabular}

Table 3 Relevant ion concentrations of the injected tap ('tap water DGF') and aquifer water used in the field experiment, and the tap water used in the autoclave experiments ('tap water MUC')

\begin{tabular}{|c|c|c|c|}
\hline Parameter & Tap water DGF & Aquifer water & Tap water MUC \\
\hline$T,{ }^{\circ} \mathrm{C}$ & 13 & 23 & 19 \\
\hline $\mathrm{pH},-$ & 7.43 & 7.01 & 7.61 \\
\hline Redox, mV & -253 & -146 & -264 \\
\hline TDS,mg/L & 525 & 922 & 391 \\
\hline $\mathrm{Na}^{+}, \mathrm{mmol} / \mathrm{L}$ & 0.18 & 7.7 & 0.16 \\
\hline $\mathrm{K}^{+}, \mathrm{mmol} / \mathrm{L}$ & 0.02 & 0.40 & 0.02 \\
\hline $\mathrm{Ca}^{2+}, \mathrm{mmol} / \mathrm{L}$ & 1.9 & 1.1 & 1.9 \\
\hline $\mathrm{Mg}^{2+}, \mathrm{mmol} / \mathrm{L}$ & 1.4 & 0.97 & 0.75 \\
\hline $\mathrm{Ba}^{2+}, \mathrm{mmol} / \mathrm{L}$ & 0.0002 & 0.0017 & 0.0003 \\
\hline $\mathrm{Sr}^{2+}, \mathrm{mmol} / \mathrm{L}$ & 0.0018 & 0.011 & 0.016 \\
\hline $\mathrm{Zn}^{2+}, \mathrm{mmol} / \mathrm{L}$ & 0.00001 & 0.00207 & 0.00028 \\
\hline $\mathrm{Cl}^{-}, \mathrm{mmol} / \mathrm{L}$ & 0.40 & 4.1 & 0.16 \\
\hline $\mathrm{NO}_{3}^{-}, \mathrm{mmol} / \mathrm{L}$ & 0.25 & $<0.0016$ & 0.09 \\
\hline $\mathrm{SO}_{4}^{2-}, \mathrm{mmol} / \mathrm{L}$ & 0.13 & 0.21 & 0.41 \\
\hline $\mathrm{HCO}_{3}^{-}, \mathrm{mmol} / \mathrm{L}$ & 5.7 & 7.7 & 4.6 \\
\hline $\mathrm{Mg} / \mathrm{Ca}$ & 0.72 & 0.88 & 0.39 \\
\hline $\mathrm{p}\left(\mathrm{CO}_{2}\right)$, bar & 0.038 & 0.035 & 0.009 \\
\hline SI calcite & -0.19 & -0.19 & 0.16 \\
\hline SI aragonite & -0.35 & -0.33 & 0.02 \\
\hline SI vaterite & -0.79 & -0.76 & -0.43 \\
\hline
\end{tabular}

The calculated partial pressures of $\mathrm{CO}_{2}$ and $\mathrm{SI}$ are listed below (tap water for $T=20^{\circ} \mathrm{C}$ and $p_{\text {total }}=1$ bar; aquifer water refers to reservoir conditions)

to reduce artifacts and contaminations. In contrast to other filtration devices, the gas composition of the fluid is kept almost untouched, which is very important for samples containing $\mathrm{CO}_{2}$. Polycarbonate filters $(d=47 \mathrm{~mm}$; pore size: $10,5,2,1$, and $0.1 \mu \mathrm{m}$ ) were purchased from Pieper Filters, Germany. The filters were left to dry in PE petri dishes (Greiner Bio-One, Austria) after filtration.

The filtered volume for the samples collected in the field experiment was $1 \mathrm{~L}$ for $10-1 \mu \mathrm{m}$ pore size filters and $0.5 \mathrm{~L}$ for $0.1 \mu \mathrm{m}$ pore size filters. One sample was analyzed for each injection temperature, while several samples were analyzed during production $\left(n=12\right.$ at $T_{\text {Inj }}<110^{\circ} \mathrm{C}, n=8$ at $\left.T_{\text {Inj }}=110^{\circ} \mathrm{C}\right)$. The filtrated volume in the autoclave experiment was $0.5 \mathrm{~L}$, and 25 samples were analyzed in total. 


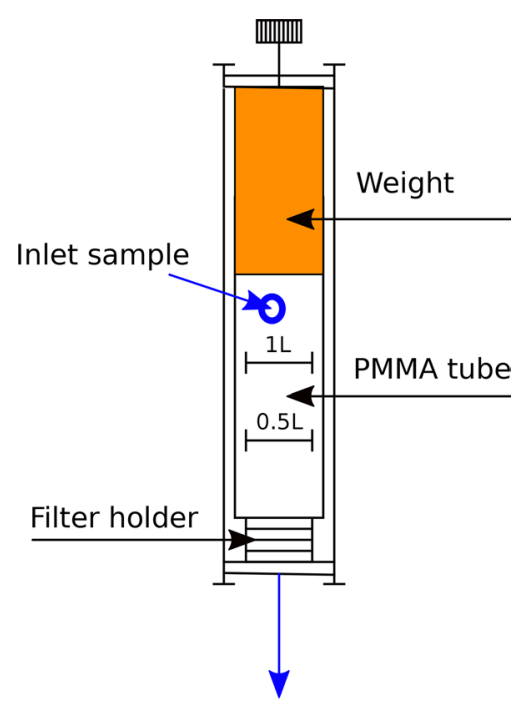

Outlet filtrate

Fig. 4 Sketch of the filtration device used for particle size separation. A PMMA tube allows water filtration with reduced turbulences through PTFE filter holder. A weight pushing down on the water allows faster filtration at smaller pore sizes

The description of the particles collected on the filters were determined using SEM/ EDX (Stereoscan 360/Röntec Leica, Cambridge, UK). Filters were sputtered with gold. Selected samples were cross-checked by Raman microscopy (LabRAM HR, HORIBA Scientific, Japan) to validate the morphological determination by SEM/EDX.

The quantification of the particle concentration of the field experiment samples was determined by weighing (Balance ID: L106290, Mettler). Blanks were weighted for each pore size. In total, 50 sample filters were weighted.

To determine the elemental composition of the filtered particles the filters were covered by $36 \% \mathrm{HCl}$ (s.p.) in a reaction vessel and dissolved at $200^{\circ} \mathrm{C}$ by microwave acid digestion (Berghoff, Germany) and then analyzed by ICP-MS (Elan 6100, Perkin-Elmer, Waltham, USA). For each run, including 12 reaction vessels, we did an acid blank and one filter blank (filter+acid).

\section{Results}

\section{Particle description of the autoclave experiments}

\section{Autoclave experiments with tap water MUC}

The $\mathrm{p}\left(\mathrm{CO}_{2}\right)$ varied between 0.008 and 0.019 bar from 45 to $110^{\circ} \mathrm{C}\left(\mathrm{SI}_{\text {calcite }}=0.70-1.47\right)$ in the tap water experiments with air and between 0.012 and 0.024 bar from 45 to $110^{\circ} \mathrm{C}$ $\left(\mathrm{SI}_{\text {calcite }}=0.52-1.39\right)$ in the tap water experiments with $\mathrm{CO}_{2}$. The $\mathrm{Mg} / \mathrm{Ca}$ ratio in all experiments was 0.39 . The tap water was in quasi-equilibrium with calcium carbonate prior to heating the autoclave, and preexisting crystals were rather unlikely.

Figure 5 shows characteristic images of the filters obtained in the tap water experiments. At temperatures of $45-80{ }^{\circ} \mathrm{C}$ wheat-sheaf aragonites were dominating. Also spherical aragonites were found at $80^{\circ} \mathrm{C}$. Acicular aragonites were only observed at temperatures of $110^{\circ} \mathrm{C}$. Single crystals as well as aggregates were found in these experiments. 


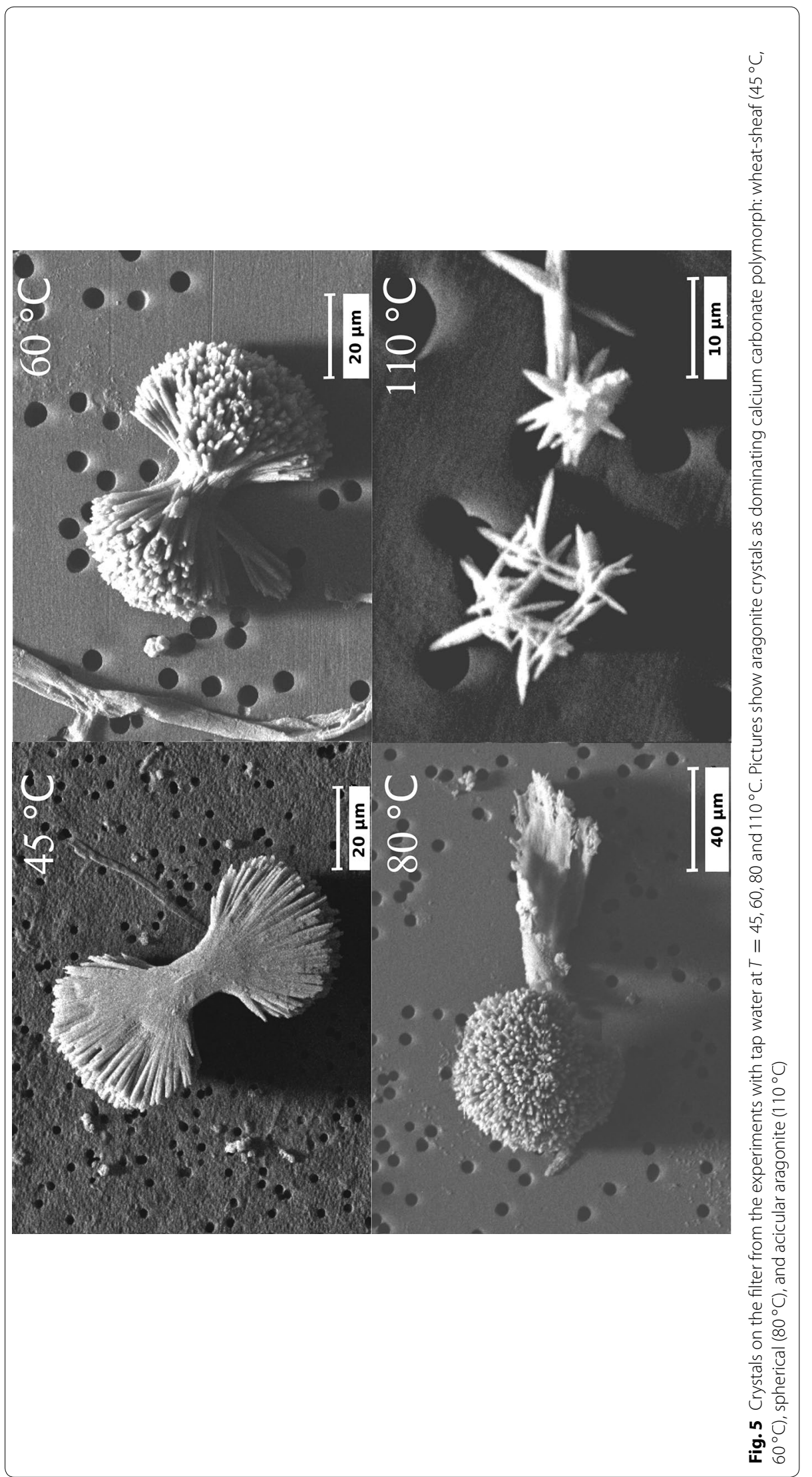


Calcite crystals in a typical rhombohedral habit were not found. The absence of rhombohedral calcite crystals is surprising, at least at $45^{\circ} \mathrm{C}$. Similar crystals were found in all experimental runs with tap water, regardless of the partial pressures in the gas phase (air vs. argon and $\left.\mathrm{CO}_{2}\right)$ and regardless whether rock samples were present in the vessel or not. The results suggest a formation of aragonite due to the increasing temperature. The higher the temperature, the more pronounced the needle-like structure habit.

These setups result in an increase in temperature simultaneously to an increase in supersaturation.

\section{Autoclave experiments with ultra-pure water}

The $\mathrm{p}\left(\mathrm{CO}_{2}\right)$ varied between 0.0006 and 0.0013 bar from 45 to $110^{\circ} \mathrm{C}$, and the water is strongly undersaturated with respect to calcium carbonate. Calcium and magnesium ion concentrations in the solution after heating (= dissolution of the rock matrix) varied from about 0.22 and $0.04 \mathrm{mmol} / \mathrm{L}$ (limestone) to 0.78 and $0.82 \mathrm{mmol} / \mathrm{L}$ (dolomite), depending on the matrix composition. As a consequence, the $\mathrm{Mg} / \mathrm{Ca}$ ratio varied between 0.2 and 1 .

Rhombohedral shaped calcite crystals were found at temperatures from 45 to $110^{\circ} \mathrm{C}$ (see Fig. 6). Mostly aggregates with a compact habit were built (temperature of $45-80^{\circ} \mathrm{C}$ ), but at a temperature of $110^{\circ} \mathrm{C}$ micropores were visible. Almost no single crystals were found. Smaller crystals adhered on the surface of bigger ones, and grew there. No aragonite crystals were observed on the filters.

The solution is undersaturated with respect to $\mathrm{CaCO}_{3}$, and preexisting crystals were rather unlikely. After dissolution of the rock matrix, additional ions are present in the solution. It is likely that some homogeneous nucleation occurred at low, local supersaturation in the vicinity of the rock sample. However, the magnesium ion concentration had no impact on the crystal habit of the newly formed crystals.

\section{Quantification of the particle concentration}

The particle mass was below the limit of detection $(1 \mathrm{mg} / \mathrm{L}$ by weighing) in the laboratory and the field experiment. Also the elements determined in the supernatant of the digested filters by ICP/MS were below the limit of detection in both experimental setups. Thus, a semi-quantitative assessment based on SEM images was applied.

The addition of $\mathrm{CO}_{2}$ to the tap water led to a very low particle concentration of the heated water in the field experiment. The particle size distribution was strongly shifted towards smaller particles on the $0.1 \mu \mathrm{m}$ filters (see Fig. 7, Pictures 1-5). A muddy matrix accumulated on the $0.1 \mu \mathrm{m}$ filter (see Fig. 7, Picture 5 and Fig. 9).

The particle concentration increased slightly during production. We assume that this is due to an increase of the concentrations of calcium-, magnesium- and bicarbonate ions due to dissolution of the matrix, followed by particle growth (see Fig. 8).

\section{Particle description of the field experiment}

The $\mathrm{p}\left(\mathrm{CO}_{2}\right)$ varied between 0.26 and 1.1 bar from 65 to $110^{\circ} \mathrm{C}$, and the corresponding saturation index for calcite varied between -0.13 at $65^{\circ} \mathrm{C}$ and 0.16 at $110^{\circ} \mathrm{C}$. The initial $\mathrm{Mg} / \mathrm{Ca}$ ratio during all injection stages was 0.72 , and the median during production stages was 0.67 ( 0.44 was the lowest and 1.35 the highest ratio). The ratio 


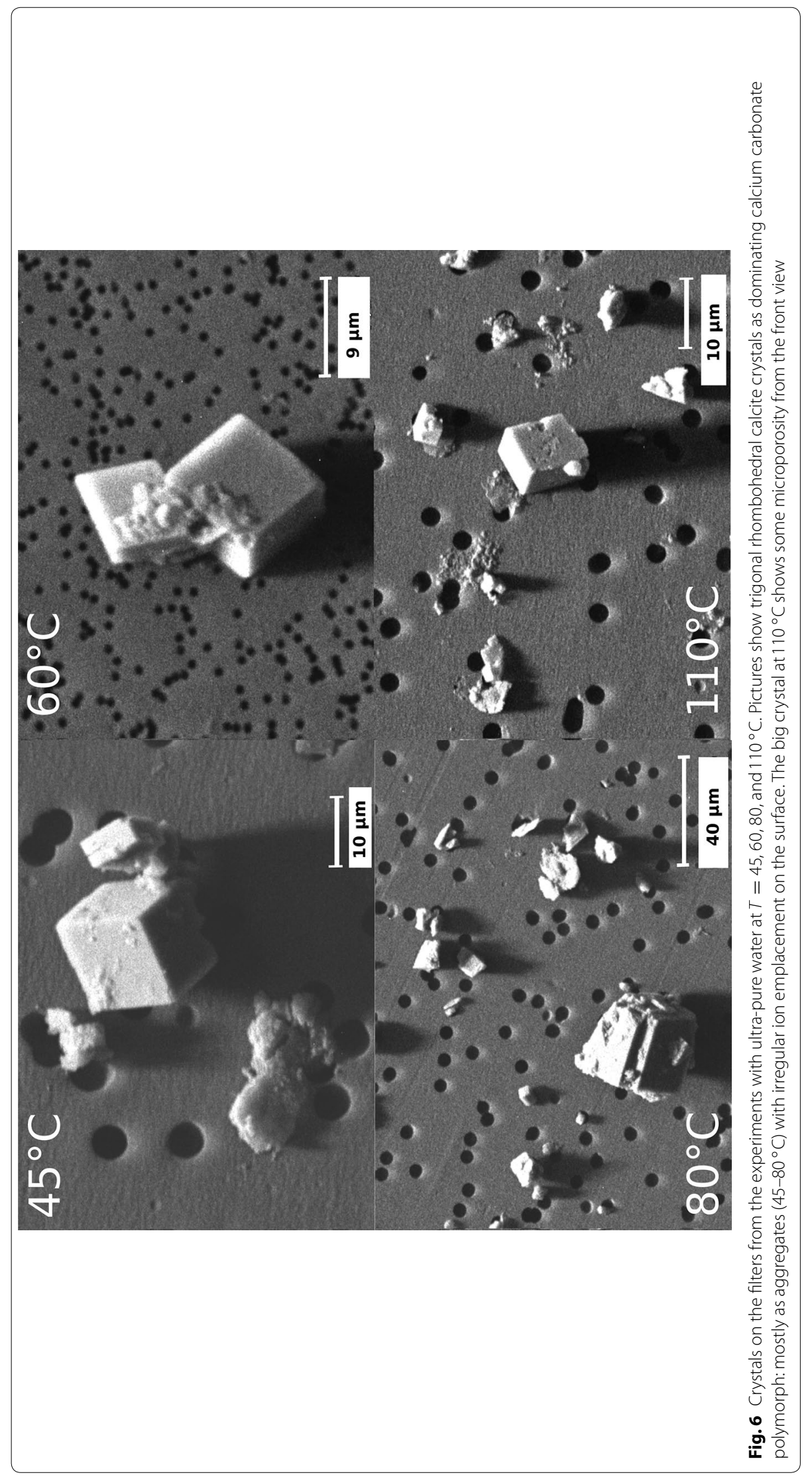



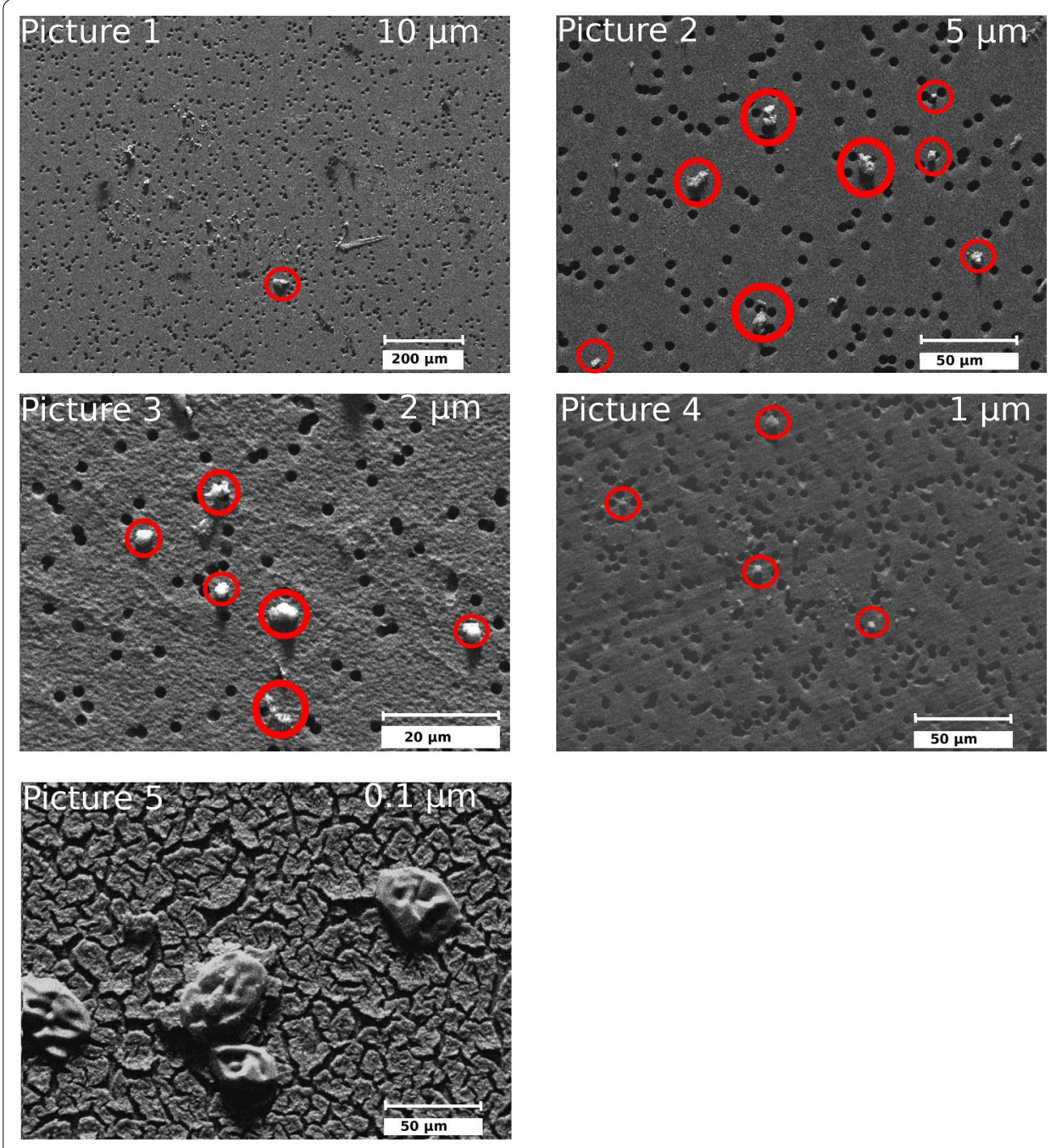

Fig. 7 Overview of particles collected at the field site (here, at an injection temperature of $90^{\circ} \mathrm{C}$ ): low particle load on the filters with pore sizes of $10 \mu \mathrm{m}$ to $1 \mu \mathrm{m}$ (see picture 1-4) due to the $\mathrm{CO}_{2}$ addition. Only filters with $0.1 \mu \mathrm{m}$ pore sizes had a significant particle load (see picture 5). Mostly rounded particles are visible at pore sizes of $1-10 \mu \mathrm{m}$ (see red circles). Pore sizes of $0.1 \mu \mathrm{m}$ showed a muddy matrix, and no crystals can be identified

depended on the dissolved reservoir matrix and varied through all stages. All other divalent cations had very low concentrations $(<0.02 \mathrm{mmol} / \mathrm{L})$. Sulfate ions had low concentrations (between $0.1-0.2 \mathrm{mmol} / \mathrm{L}$ ).

The same crystal morphologies were observed during injection (see Figs. 10 and 11, Picture 2) and production stages (see Figs. 10 and 11, Picture 1 and 3). EDX measurements show that the particles on the $10-1 \mu \mathrm{m}$ filters mainly consists of calcium carbonate (Fig. 8 Pic. 1-4). No crystals can be identified, but EDX measurements as well as element mapping suggest iron precipitates on the filters with $0.1 \mu \mathrm{m}$ pore sizes (Fig. 8, Picture 5). Modeling with PhreeqC and a Pourbaix diagram at the given $\mathrm{pH}-$ Eh conditions indicates iron hydroxides (Ueckert 2016). The cracks shown in Fig. 9 likely developed during drying of the filters. 


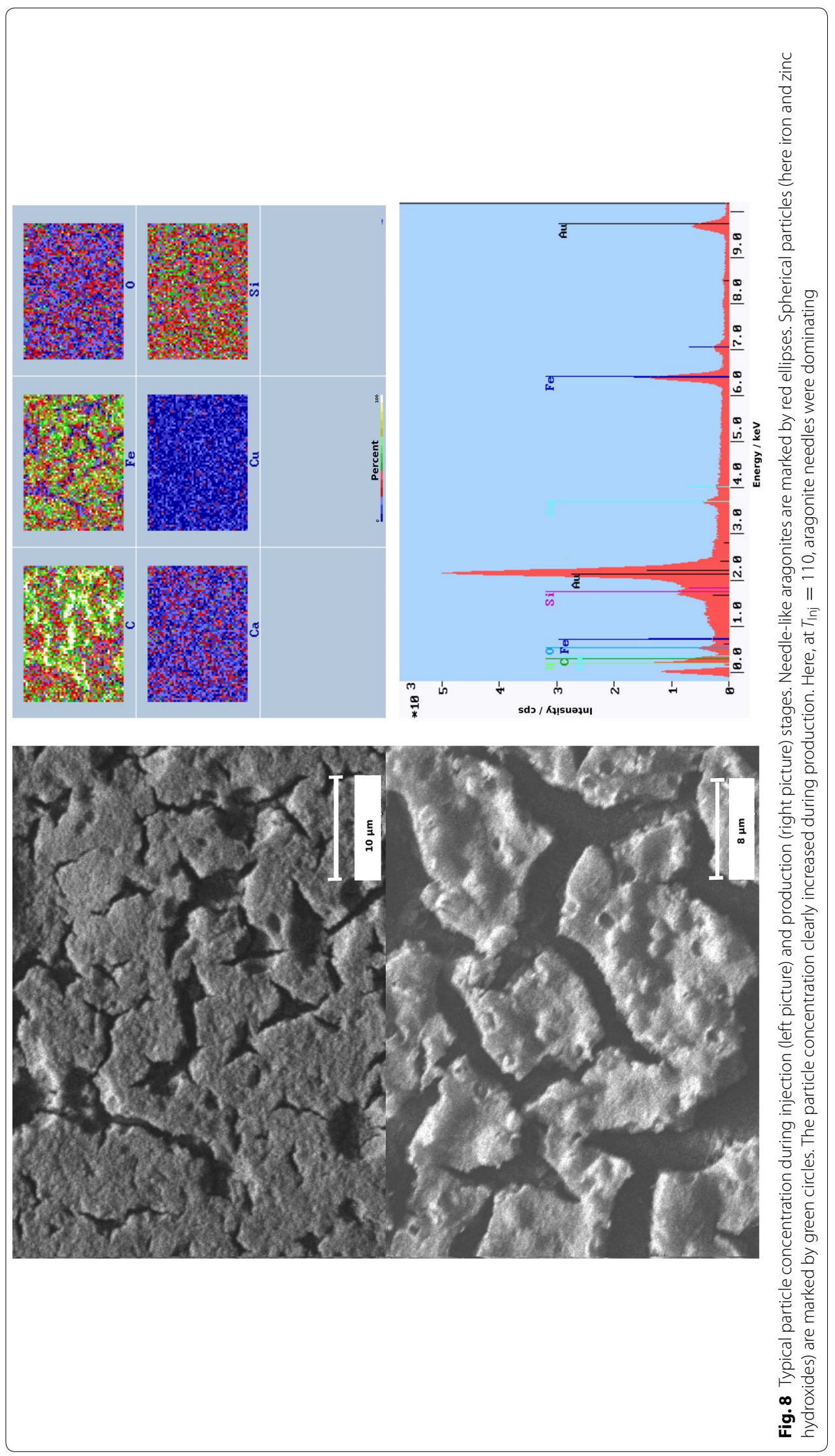




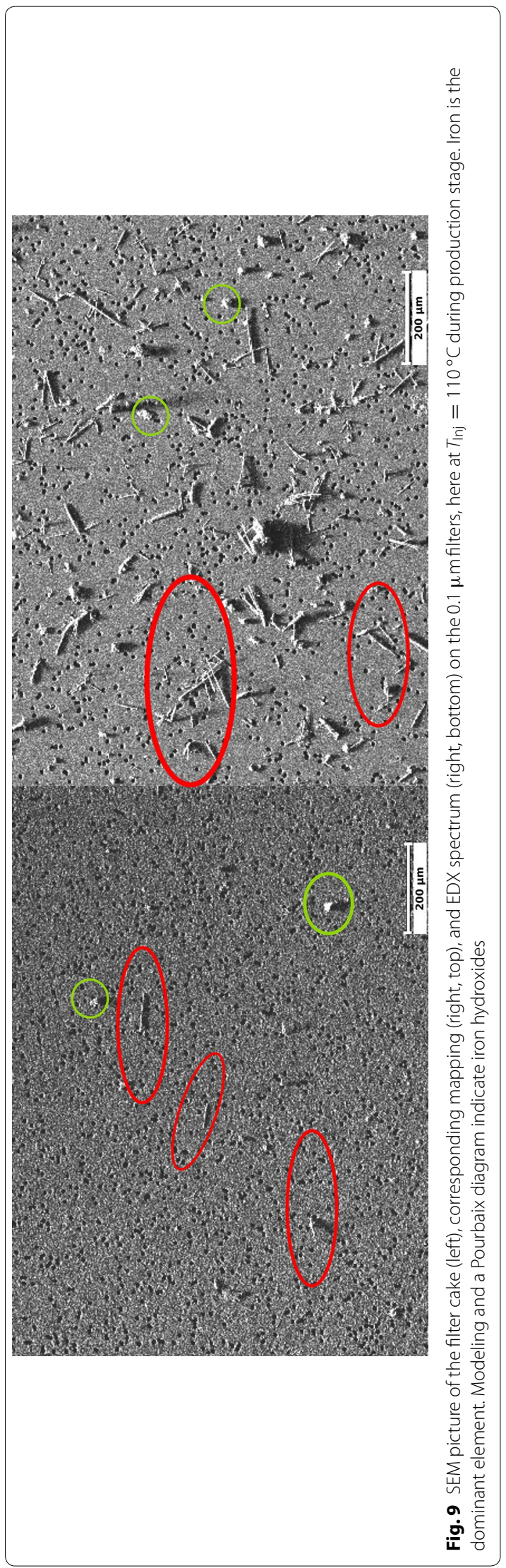



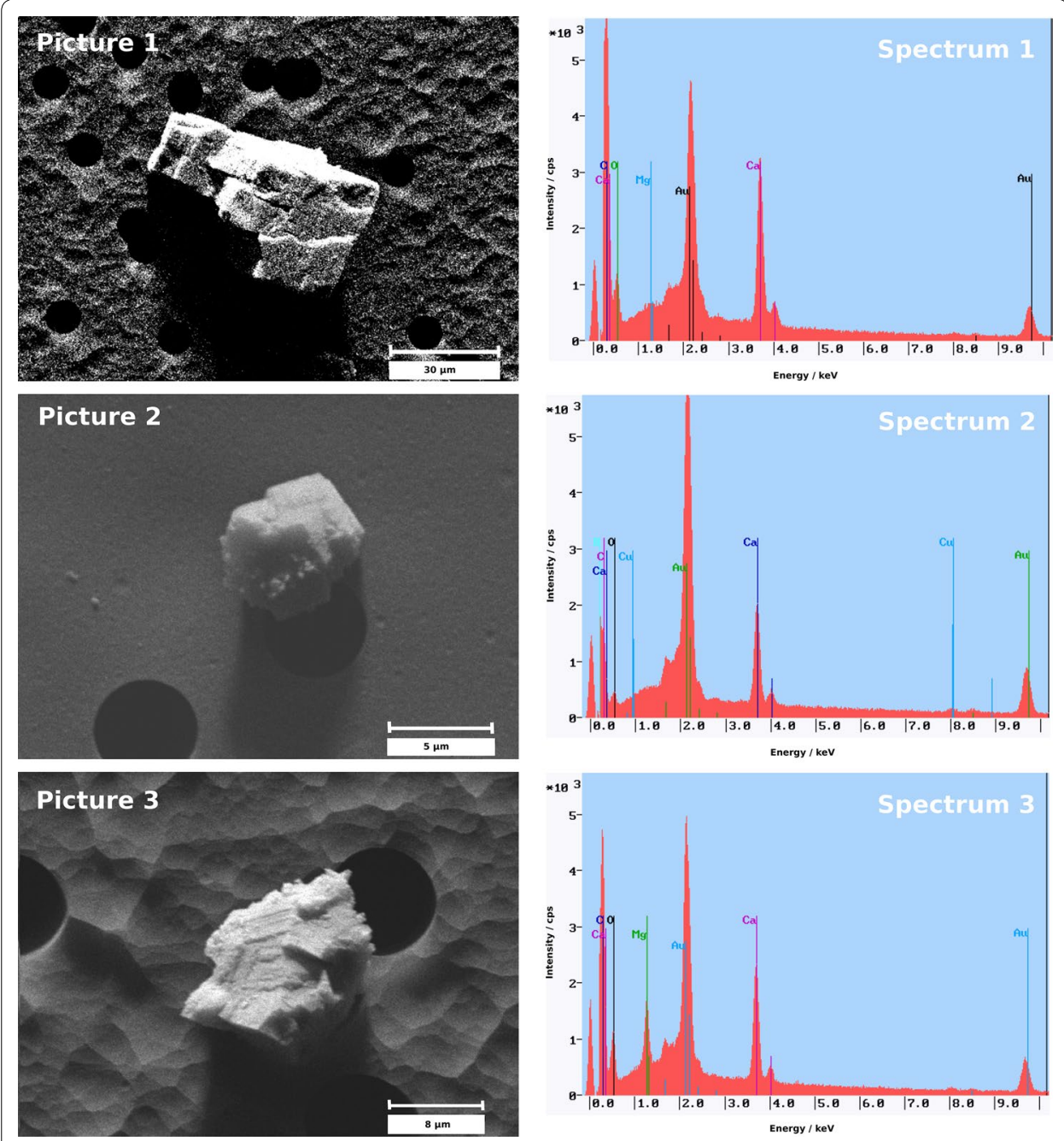

Fig. 10 Typical carbonate crystals during $T_{\operatorname{lnj}}=65,80$, and $90^{\circ} \mathrm{C}$ : SEM picture (left) and corresponding EDX spectrum (right). Examples for injection at $80^{\circ} \mathrm{C}$ (Picture 2) and production at $45^{\circ} \mathrm{C}$ (Picture $1, T_{\text {Inj }}=65^{\circ} \mathrm{C}$ ) and at $31^{\circ} \mathrm{C}$ (Picture $3, T_{\text {Inj }}=80^{\circ} \mathrm{C}$ ). All pictures at these injection temperature indicate irregular calcite crystallization. Still, the morphology suggests rhombohedral calcite crystals. Some of these crystals are magnesium bearing (see Picture 3)

According to the SEM measurements, no aragonite crystals could be identified, neither during injection $\left(T=65-90^{\circ} \mathrm{C}\right)$ nor during production. The particles at this injection temperature generally showed a compact rhombohedral habit indicating calcites (Fig. 10), which got partly dissolved (Picture 1), or grew irregularly (Picture 2 and 3). Partly, EDX measurements suggest magnesium bearing particles (see Fig. 10, Picture 3). EDX suggest partly very small amounts of copper.

However, once the injection temperature was set to $110^{\circ} \mathrm{C}$, acicular aragonite crystals prevailed (Fig. 11, Pictures 1-3). Even when the temperature decreased to $37^{\circ} \mathrm{C}$, after $92 \mathrm{~h}$ of production (see Fig. 11, Picture 1), aragonite crystals were dominating. EDX measurements suggest small peaks of other elements (e.g., copper and zinc), but no magnesium, strontium or barium peaks were measured. 

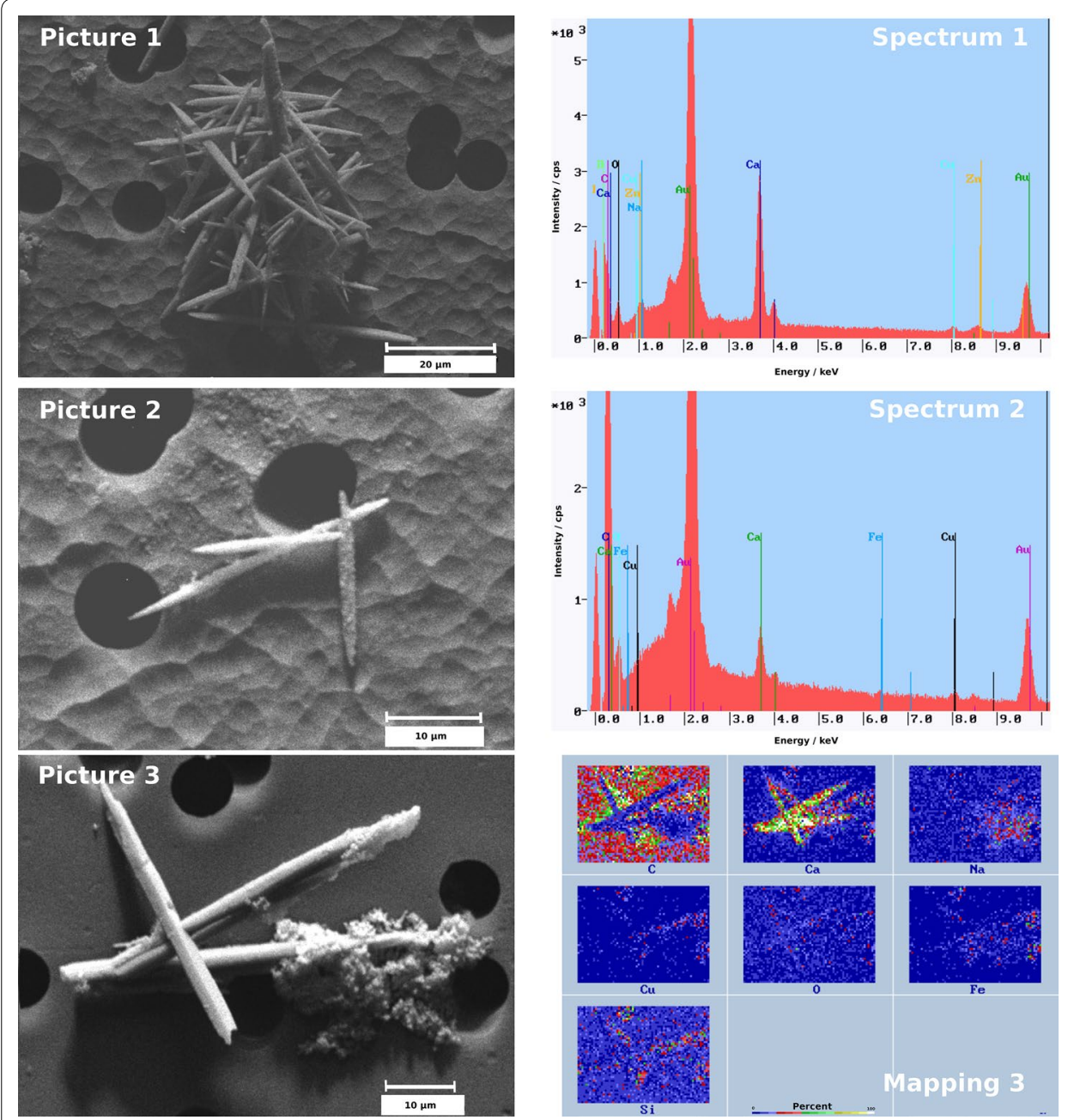

Fig. 11 Typical carbonate crystals during $T_{\text {Inj }}=110^{\circ} \mathrm{C}$ : SEM picture (left) and corresponding EDX spectrum resp. mapping (right). Examples for injection (Picture 2) and production at $37^{\circ} \mathrm{C}$ (Picture 1) $60^{\circ} \mathrm{C}$ (Picture 3). All pictures at these injection temperatures show acicular aragonite crystals

Neither vaterite crystals nor any spherical crystals were detected on any filter sample. Although the filters were analyzed randomly and the content of vaterite is usually significantly lower than the stable polymorphic forms of $\mathrm{CaCO}_{3}$ (e.g., Wang et al. (2013): 8-20\%), the analyses should have identified at least some vaterite spheres, had they been present.

\section{Discussion}

In the laboratory experiments with tap water MUC the SI for calcite was close to equilibrium prior to heating, therefore no (or almost no) concentration gradient was present. Here, temperature predominately controlled the reaction. No difference in the crystallization with or without $p\left(\mathrm{CO}_{2}\right)$ was seen. The influence seemed negligible at low $\mathrm{CO}_{2}$ partial pressures up to 24 mbar (at $110^{\circ} \mathrm{C}$, with $\mathrm{CO}_{2}$ addition). However, within our experimental range, the level of supersaturation strongly depended on the increase of temperature. We saw no influence on the affinity to crystallize as aragonite or calcite 
$\left(\mathrm{SI}_{\text {calcite }} 0.52-1.47\right)$, as aragonite crystals were always prevailing. According to the literature (see e.g., Bots et al. 2011), a low $\mathrm{Mg} / \mathrm{Ca}$ ratio of 0.39 , and the low sulfate ion concentrations of $0.4 \mathrm{mmol} / \mathrm{L}$ should not inhibit calcite crystallization. However, aragonite crystals prevailed, even at $45^{\circ} \mathrm{C}$. For temperatures up to $60^{\circ} \mathrm{C}$ wheat-sheaf aragonites were seen in the SEM-pictures. At temperatures of $110^{\circ} \mathrm{C}$ acicular aragonite crystals were predominant (see Fig. 5). Since no aragonite particles were found in the water at $20^{\circ} \mathrm{C}$, homogeneous nucleation can be assumed. No macroscopically visible precipitates were found on the rock samples or in the reaction vessel.

In contrast to the tap water experiments, temperature increase did not come not along with supersaturation in the ultra-pure water experiments. The solution was strongly undersaturated with respect to calcium carbonate. Therefore, a concentration gradient between rock sample and ultra-pure water existed. Once the solution was heated, matrix got dissolved, and a low local supersaturation occurred. Here, only calcite crystallized and no aragonite crystals were observed, even at temperatures of $110^{\circ} \mathrm{C}$. This might have been linked to the strong concentration gradient, which favors the crystallization of calcite over aragonite, or by the low supersaturation (Wang et al. 2013). Calcite crystallization should be inhibited by magnesium ion concentrations (Chen et al. 2006; Reddy and Nancollas 1976). The dissolution of the rock matrix changed the $\mathrm{Mg} / \mathrm{Ca}$ ratio from 0.2 to 1 , but no influence on the crystallization of the $\mathrm{CaCO}_{3}$ polymorphs was seen. At least at these low ion concentrations of maximum $0.78 \mathrm{mmol} / \mathrm{L}$ calcium ions and $0.82 \mathrm{mmol} / \mathrm{L}$ magnesium ions, no inhibition of the calcite crystallization was seen. No nuclei were initially present in the solution, and homogeneous nucleation occurred. However, most crystals existed as aggregates which suggest a subsequent growth on the initial crystals.

In summary, no influence of foreign ions and temperature on the crystallization of $\mathrm{CaCO}_{3}$ polymorphs was seen in the autoclave experiments. We assume that the level of supersaturation strongly influenced the crystallization of the $\mathrm{CaCO}_{3}$ polymorphs. Calcite crystals were dominant at low supersaturation, and aragonite crystals at saturation indices above 0.50 .

The autoclave experiments at very well-defined conditions served as a benchmark for the processes and the models. However, they were never intended to mimic the field conditions, which is not necessary if the underlying conceptual framework can be tested with that experiment.

During the field experiment, we produced $15 \mathrm{~L} / \mathrm{s}, 11^{\circ} \mathrm{C}$ cold carbonate tap water at atmospheric conditions which was in quasi-equilibrium with calcite. Prior to heating, $\mathrm{CO}_{2}$ was added to the water and the water was strongly undersaturated with respect to calcium carbonate. Heating in the plate heat exchangers brought the SI for calcite to $0.1-0.2$ (slight supersaturation). Since the injection temperatures were high, and we had foreign ions, especially magnesium ions, in the solution we expected to find mainly aragonite particles. Surprisingly, calcite crystals prevailed at injection temperatures of $65-90{ }^{\circ} \mathrm{C}$, and aragonites were only present at injection temperatures of $110^{\circ} \mathrm{C}$. The non-ideal crystallization of calcites during injection stages can be explained by low supersaturation of the tap water due to $\mathrm{CO}_{2}$ addition, and by undirected growth which points to turbulent flow. Due to the results of the autoclave experiments, we assume that the low supersaturation inhibited aragonite crystallization. The pressure was with 25 bar 
above bubble pressure (2.9 bar). Sharp pressure drops that occur in submersible pumps are absent in our setup. Thus degassing was rather unlikely. We had turbulent flow in the pipe $\left(\operatorname{Re}=120,000\right.$, at $20^{\circ} \mathrm{C}$ and $\left.15 \mathrm{~L} / \mathrm{s}\right)$, and we can also safely assume turbulences in the karstic system close to the borehole where flow velocities were high. We can therefore assume that no diffusion-limited conditions were existent.

Once the injected tap water reached the aquifer, a thermal equilibrium was established by mixing with the water in the reservoir and heat exchange with the matrix. The initial sharp temperature drop was followed by a slower decrease as the injected water propagates into the matrix. The decrease of the temperature caused a sharp decrease of the SI for calcite. The water became undersaturated with respect to calcite, and dissolved the carbonate matrix (Ueckert and Baumann 2019). Crystal nuclei and crystals in the water should also have been dissolved. After fast dissolution of carbonates in the aquifer to reach equilibrium with the rock matrix, the water became supersaturated during production, which caused crystal nuclei to grow irregularly under turbulent flow conditions (Han et al. 2004).

Interestingly, we did not see differences in the crystal habit during production, compared to the injection stages. At injection temperatures of $65-90^{\circ} \mathrm{C}$, and the following production stages, far from ideal rhombohedral calcites were characterized. At injection temperatures of $110^{\circ} \mathrm{C}$, and the following production stages, acicular aragonite crystals were detected, even after a production time of $92 \mathrm{~h}$, when the water had a minimum temperature of $37^{\circ} \mathrm{C}$. The crystals at the corresponding production stage showed the same polymorphism. If detrital mobilization had occurred, one would not expect single crystals or varying polymorphs at different temperatures. We further assume that we had some homogeneous nucleation, but based on our data we are not able to distinguish if we had additionally heterogenous nucleation, e.g., on tiny iron hydroxide crystals.

Calcite crystallization was favored in the autoclave experiments with ultra-pure water, and in the field experiment up to temperatures of $90^{\circ} \mathrm{C}$, because of the low supersaturation (Wang et al. 2013). These calcites in the field experiment grew irregularly and mostly as compact single crystals. Even if aragonite crystals were suddenly dominating at $110^{\circ} \mathrm{C}$, it is surprising that aragonites were stable for at least $92 \mathrm{~h}$ at a minimum temperature of $37^{\circ} \mathrm{C}$. This is counter-intuitive because the strong undersaturation should lead to dissolution or at least shrinking size. Since the crystals of the injection and production stages were similar, although the boundary conditions changed, we assume that the dissolution of the crystals in the injected tap water was slow, and crystal nuclei were stable through the dissolution of the aquifer matrix. During production, these nuclei grew by additional ions in the solution.

This hypothesis results in the assumption that crystal nuclei and crystals will be transported between the wells of an operating system. That might be favorable for operation because it reduces precipitates at the wall of the pipes and the heat exchangers, as long as they are kept in solution.

\section{Conclusion}

Increasing temperature from 45 to $110^{\circ} \mathrm{C}, \mathrm{Mg} / \mathrm{Ca}$ ratios up to 1 , as well as low $\mathrm{p}\left(\mathrm{CO}_{2}\right)$ (up to 24 mbar) had no influence on the crystallization of the $\mathrm{CaCO}_{3}$ polymorphs in the autoclave experiments. It seems that supersaturation controlled the $\mathrm{CaCO}_{3}$ 
polymorphs. Only aragonite crystals were morphologically identified in the tap water experiments. Lower temperatures up to $60^{\circ} \mathrm{C}$ resulted in wheat-sheaf structures, and the higher the temperature the more acicular aragonites prevailed. A strong concentration gradient and undersaturation in the ultra-pure water experiments resulted in exclusive calcite crystallization, even at high temperatures of $110^{\circ} \mathrm{C}$, and high $\mathrm{Mg} / \mathrm{Ca}$ ratios of 1 .

The push-pull heat storage test was in line with the results of the laboratory tests showing that varying $\mathrm{Mg} / \mathrm{Ca}$ ratios, and $\mathrm{p}\left(\mathrm{CO}_{2}\right)$ had no influence on the crystallization of the $\mathrm{CaCO}_{3}$ polymorphs. The low supersaturation within the quasi-equilibrium up to $90^{\circ} \mathrm{C}$ resulted in calcite crystallization. Turbulent flow was the reaction-controlling process, and inhibited the crystallization due to irregular growth. Aragonite crystals prevailed at injection temperatures of $110^{\circ} \mathrm{C}$.

Surprisingly, $\mathrm{CaCO}_{3}$ polymorphs were similar between injection and the following production stage. Based on these observations, we assume that nuclei and crystals were already injected during the injection stages. Once the water reached the aquifer and was cooling, dissolution of the aquifer matrix occurred and more calcium and magnesium ions were available in the water. As a consequence, existing nuclei were able to grow and were produced during production stages in their injected polymorphic form.

Even if the solubility products of aragonite and calcite are related, it is necessary to establish a sound knowledge of the crystallization of the calcium carbonate polymorphs in natural systems to avoid precipitations. In our experiments, we have shown the first results, and possible explanations of the crystallization of $\mathrm{CaCO}_{3}$ in geothermal systems. The next step should be an investigation of $\mathrm{CaCO}_{3}$ polymorphs by in situ experiments. The conditions in a full-scale aquifer heat storage system are very similar to the push-pull test, except that the cooling of the water takes place in heat exchangers above ground and the dissolution is occurring at the cold well. We expect that crystals are transported between the wells, which is favorable for the operation, because this reduces precipitation at the walls of pipes and heat exchangers. These particles should therefore be kept in solution, rather than removing them by filters.

\footnotetext{
Abbreviations

DGF: Sample name: tap water in the field experiment; ICP-MS: Inductively coupled plasma mass spectrometry; MUC: Sample name: tap water in the autoclave experiment; UPW: Ultra-pure water; SEM/EDX: Scanning electron microscope/ energy-dispersive X-ray spectroscopy; SI: Saturation Index; TDS: Total dissolved solids; TInj: Injection temperature of the tap water at the field experiment; $T_{\text {Prod: }}$ Production temperature of the tap water at the field experiment; PE: Polyethylene; PMMA: Polymethylmethacrylate; PTFE: Polytetrafluoroethylene.
}

\section{Acknowledgements}

The financial support by the Bayerisches Staatsministerium für Wirtschaft und Medien, Energie und Technologie and the BMW Group is gratefully acknowledged. We would like to thank our colleagues Sebastian Wieseman and Roland Hoppe for technical improvements of the autoclave and constructing the filtration device. Christine Benning is gratefully acknowledged for SEM/EDX and ICP-MS measurements. Thank you, Philipp Anger, for Raman microscopy measurements. We would like to thank our cooperation partners Daniel Bohnsack and Dr. Kai Zosseder, Chair of Hydrogeology at TUM, for providing us data of the rock properties. Last but not least, we want to thank Prof. Dr. Hans-Jörg Vogel and PD Dr. Maximilian Köhne, Chair of Soil System Science at the UFZ Halle, for the CT images!

\section{Authors' contributions}

MU planned, organized, and performed the field experiments and evaluation, planned and evaluated the autoclave experiments and did the graphical representation. CW organized and performed the autoclave experiments. TB had the idea, designed and implemented the evaluation routines of the field test. All authors read and approved the final manuscript. 


\section{Availability of data and materials}

The datasets used and analyzed during the current study are available from the corresponding author on reasonable request.

\section{Competing interests}

The authors declare that they have no competing interests.

\section{Author details}

${ }^{1}$ Institute of Hydrochemistry, Technical University of Munich, Marchioninistr. 17, 81377 Munich, Germany. ${ }^{2}$ Chair of Hydrogeology, Technical University of Munich, Arcisstr. 21, 80333 Munich, Germany.

Received: 23 May 2019 Accepted: 20 January 2020

Published online: 05 February 2020

\section{References}

Aggarwal PK, Gat JR, Froehlich KFO. Isotopes in the water cycle: past, present, and future of a developing science. Berlin: Springer; 2005.

Ahn J-W, Kim J-H, Park H-S, Kim J-A, Han C, Kim H. Synthesis of single phase aragonite precipitated calcium carbonate in $\mathrm{Ca}(\mathrm{OH})_{2}-\mathrm{Na}_{2} \mathrm{CO}_{3}-\mathrm{NaOH}$ reaction system. Kor J Chem Eng. 2005:22:852-6. https://doi.org/10.1007/BF02705664.

Andritsos N, Karabelas AJ. Calcium carbonate scaling in a plate heat exchanger in the presence of particles. Int J Heat Mass Transf. 2003:46(24):4613-27. https://doi.org/10.1016/50017-9310(03)00308-9.

Appelo CAJ, Postma D. Geochemistry, groundwater and pollution. Amsterdam: A.A. Balkema Publishers; 2005.

Bartels J, Baumann T, Bohnsack D, Huber B, Schubert A, Steiner U, Ueckert M, Wenderoth F, Zosseder K. Forschungsvorhaben Hochtemperatur Aquiferspeicher Schlussbericht Phase 1. Tech. rep., Eine Kooperation der Aquasoil GmbH, Erdwerk GmbH und Technischen Universität München; 2015.

Baumann T. Validation of hydrochemical analyses and gas concentrations of deep geothermal aquifers. In: Proceedings, 41 st workshop on geothermal reservoir engineering, Stanford University, Stanford, Kalifornien. SGP-TR-209. 2016;2016.

Baumann T, Bartels J, Lafogler M, Wenderoth F. Assessment of heat mining and hydrogeochemical reactions with data from a former geothermal injection well in the malm aquifer, bavarian molasse basin, germany. Geothermics. 2017;66:50-60. https://doi.org/10.1016/j.geothermics.2016.11.008.

Berner RA. The role of magnesium in the crystal growth of calcite and aragonite from sea water. Geochemica Cosmochimica Acta. 1975;39(4):489-504. https://doi.org/10.1016/0016-7037(75)90102-7.

Bots P, Benning LG, Rickaby REM, Shaw S. The role of $\mathrm{SO}_{4}$ in the switch from calcite to aragonite seas. Geology. 2011;39(4):331-4. https://doi.org/10.1130/G31619.1.

Chen T, Neville A, Yuan M. Influence of $\mathrm{Mg}^{2+}$ on $\mathrm{CaCO}_{3}$ formation-bulk precipitation and surface deposition. Chem Eng Sci. 2006;61(16):5318-27. https://doi.org/10.1016/j.ces.2006.04.007.

Chong TH, Sheikholeslami R. Thermodynamics and kinetics for mixed calcium carbonate and calcium sulfate precipitation. Chem Eng Sci. 2001;56:5391-400. https://doi.org/10.1016/S0009-2509(01)00237-8.

Clarke I, Fritz P. Environ Isotop Hydrogeol. Boca Raton: CRC Press; 1997.

De Yoreo J, Vekilov PG. Principles of crystal nucleation and growth. Rev Mineral Geochem. 2003;54(1):57-93. https://doi. org/10.2113/0540057.

Elliot JR, Lira CT. PREOS.XLS: A workbook for use with 'An introduction to applied thermodynamics'. 2013; http://www.egr. msu.edu/lira/computer/EXCEL/PREOS.XLS

Gautelier M, Schott J, Oelkers EH. An experimental study of dolomite dissolution rates at $80^{\circ} \mathrm{C}$ as a function of chemical affinity and solution composition. Chem Geol. 2007;242(3-4):509-17. https://doi.org/10.1016/j.chemg eo.2007.05.008

Han YS, Hadiko G, Fuji M, Takahashi M. Effect of flow rate and $\mathrm{CO}_{2}$ content on the phase and morphology of $\mathrm{CaCO}_{3}$ prepared by bubbling method. J Cryst Growth. 2004;276:541-8. https://doi.org/10.1016/j.jcrysgro.2004.11.408.

Han YS, Hadiko G, Fuji M, Takahashi M. Factors affecting the phase and morphology of $\mathrm{CaCO}_{3}$ prepared by a bubbling method. J Eur Ceram Soc. 2006;26:843-7. https://doi.org/10.1016/j.jeurceramsoc.2005.07.050.

Jones Brian. Review of aragonite and calcite crystal morphogenesis in thermal spring systems. Sediment Geol. 2017;354:9-23. https://doi.org/10.1016/j.sedgeo.2017.03.012.

Kitamura M. Crystallization and transformation mechanism of calcium carbonate polymorphs and the effect of magnesium ion. J Coll Interf Sci. 2001;236(2):318-27. https://doi.org/10.1006/jcis.2000.7398.

Langmuir D. The geochemistry of some carbonate ground waters in central pennsylvania. Geochemica Cosmochimica Acta. 1971;35(10):1023-45. https://doi.org/10.1016/0016-7037(71)90019-6.

Lee KS. Aquifer thermal energy storage. Underground thermal energy storage. London: Springer; 2013. p. 59-93.

Littlewood JL, Shaw S, Peacock CL, Bots P, Trivedi D, Burke IT. Mechanism of enhanced strontium uptake into calcite via an amorphous calcium carbonate crystallization pathway. Cryst Growth Des. 2017;17(3):1214-23. https://doi. org/10.1021/acs.cgd.6b01599.

Mayrhofer C, Niessner R, Baumann T. Hydrochemistry and hydrogen sulfide generating processes in the malm aquifer, bavarian molasse Basin, Germany. Hydrogeol J. 2014;22(1):151-62. https://doi.org/10.1007/s10040-013-1064-2.

Merkel B, Planer-Friedrich B. Grundwasserchemie. Heidelberg: Springer; 2002.

Meldrum F, Cölfen H. Controlling mineral morphologies and structures in biological and synthetic systems. Chem Rev. 2008;108(11):4332-432. https://doi.org/10.1021/cr8002856.

Morse JW, Wang Q, Tsio MY. Influences of temperature and Mg:Ca ratio on $\mathrm{CaCO}_{3}$ precipitates from seawater. Geology. 1997;25:85-7. 
Mundhenk N, Huttenloch P, Sanjuan B, Kohl T, Steger H, Zorn R. Corrosion and scaling as interrelated phenomena in an operating geothermal power plant. Corr Sci. 2013;70:17-28. https://doi.org/10.1016/j.corsci.2013.01.003.

Niedermayr A, Köhler SJ, Dietzel M. Impacts of aqueous carbonate accumulation rate, magnesium and polyaspartic acid on calcium carbonate formation (6-40 C). Chem Geol. 2013;340:105-20. https://doi.org/10.1016/j.chemg eo.2012.12.014.

Parkhurst D, Appelo C. Description of input and examples for phreeqc version 3-a computer program for speciation, batch-reaction, one-dimensional transport, and inverse geochemical calculations. Tech. rep., 2013;http://pubs.usgs. gov/tm/06/a43/

Plummer N, Wigley T, Parkhurst D. The kinetics of calcite dissolution in $\mathrm{CO}_{2}$-water systems at 5 to $60^{\circ} \mathrm{C}$ and 0.0 to 1.0 atm $\mathrm{CO}_{2}$. Am J Sci. 1978;278:179-216. https://doi.org/10.2475/ajs.278.2.179.

Reddy MM, Nancollas GH. The crystallization of calcium carbonate: I. Isotopic exchange and kinetics. J Coll Interf Sci. 1970; https://doi.org/10.1016/0021-9797(71)90161-5.

Reddy MM, Nancollas GH. The crystallization of calcium carbonate: IV. The effect of magnesium, strontium and sulfate ions. J Cryst Growth. 1976;35(1):33-8. https://doi.org/10.1016/0022-0248(76)90240-2.

Rodriguez-Blanco JD, Shaw S, Benning LG. The kinetics and mechanisms of amorphous calcium carbonate (ACC) crystallization to calcite via vaterite. Nanoscale. 2011;3:265-71. https://doi.org/10.1039/c0nr00589d.

Schmidt I, Zolotoyabko E, Lee K, Gjardy A, Berner A, Lakin E, Fratzl P, Wagermaier W. Effect of strontium ions on crystallization of amorphous calcium carbonate. Cryst Res Technol. 2019;54:1900002. https://doi.org/10.1002/crat.201900002

Tai CY, Chien WC. Polymorphism of $\mathrm{CaCO}_{3}$, precipitated in a constant composition environment. Am Inst Chem Eng J. 1998:44:1790-8. https://doi.org/10.1002/aic.690440810.

Tai CY, Chang MC, Wu CK, Lin YC. Interpretation of calcite growth data using the two-step crystal growth model. Chem Eng Sci. 2006:61(16):5346-54. https://doi.org/10.1016/j.ces.2006.03.047.

Ueckert M. Hochtemperaturaquiferspeicher in den Malmcarbonaten des bayerischen Molassebeckens. PhD thesis, TUM 2016.

Ueckert M, Baumann T. Hydrochemical aspects of high-temperature aquifer storage in carbonaceous aquifers: evaluation of a field study. Geotherm Energy. 2019;. https://doi.org/10.1186/s40517-019-0120-0.

Vekilov PG. What determines the rate of growth of crystals from solution? Crystal Growth Des. 2007;7(12):2796-810. https ://doi.org/10.1021/cg070427i.

Vekilov PG. Nucl Cryst Growth Des. 2010;10(12):5007-19. https://doi.org/10.1021/cg1011633.

Wanner C, Eichinger F, Jahrfeld T, Diamond LW. Causes of abundant calcite scaling in geothermal wells in the Bavarian Molasse Basin, southern Germany. Geothermics. 2017;70:324-38. https://doi.org/10.1016/j.geothermics.2017.05.001.

Wang $\mathrm{H}$, Huang W, Han Y. Diffusion-reaction compromise the polymorphs of precipitated calcium carbonate. Particuology. 2013;11(3):301-8. https://doi.org/10.1016/j.partic.2012.10.003.

Wolfgramm M, Rauppach K, Thorward K. Mineralneubildungen und Partikeltransport im Thermalwasserkreislauf geothermischer Anlagen Deutschlands In: Zeitschrift geol. Wissenschaften 2011.

Wray JL, Daniels F. Precipitation of calcite and aragonite. J Am Chem Soc. 1956;79(9):2031-4.

Zhang Y, Dawe R. Influence of Mg ${ }^{2+}$ on the kinetics of calcite precipitation and calcite crystal morphology. Chem Geol. 2000;163:129-38. https://doi.org/10.1016/S0009-2541(99)00097-2.

\section{Publisher's Note}

Springer Nature remains neutral with regard to jurisdictional claims in published maps and institutional affiliations.

\section{Submit your manuscript to a SpringerOpen ${ }^{\circ}$ journal and benefit from:}

- Convenient online submission

- Rigorous peer review

- Open access: articles freely available online

High visibility within the field

Retaining the copyright to your article

Submit your next manuscript at $\boldsymbol{\nabla}$ springeropen.com 